\title{
ENHANCEMENT OF DERMAL FIBROBLAST ISOLATION METHOD
}

Milan Zaric ${ }^{1}$, Ivana Nikolic ${ }^{1}$, Ivanka Zelen ${ }^{1}$, Marina Mitrovic ${ }^{1}$ and Zoran Milosavljevic ${ }^{2}$

${ }^{1}$ Department for Biochemistry, Faculty of Medical Sciences, University of Kragujevac, Serbia,

${ }^{2}$ Department of Histology and Embriology, Faculty of Medical Sciences, University of Kragujevac, Serbia

\section{UNAPREĐENJE METODE IZOLACIJE DERMALNIH FIBROBLASTA}

\author{
Milan Zarić ${ }^{1}$, Ivana Nikolić ${ }^{1}$ Ivanka Zelen ${ }^{1}$, Marina Mitrović ${ }^{1}$ i Zoran Milosavljević ${ }^{2}$ \\ ${ }^{1}$ Institut za biohemiju, Fakultet medicinskih nauka, Univerzitet u Kragujevcu, Kragujevac, Srbija \\ ${ }^{2}$ Institut za histologiju i embriologiju, Fakultet medicinskih nauka, Univerzitet u Kragujevcu, Kragujevac, Srbija
}

\section{ABSTRACT}

Cultivated fibroblasts have been widely used in a large number of in vitro studies. Although they readily proliferate under cell culture conditions, improvements in methods for their isolation are necessary. Here, we present our modified enzyme digestion method and compare its efficiency with commonly used techniques.

Three foreskin samples from young, middle-aged and old donors were used. The classical explant, standard enzyme digestion method with collagenase and our improved enzyme digestion method were compared for efficiency of fibroblast isolation and the time needed to achieve 95\% confluence in a 30-mm Petri dish.

The explant method was the slowest to achieve fibroblast confluence, especially with the tissues from the older donors (up to 23 days). With the standard enzyme digestion method, the skin tissue was partially digested, but the fibroblasts reached confluence much faster (the younger donor cells needed approximately 7 days to reach confluence). Our modified "mixed" enzyme digestion method was the fastest (the fibroblasts from the younger donors needed up to 5 days to reach confluence).

For studies requiring the primary isolation and cultivation of dermal fibroblasts, the best method to achieve this goal is the tissue digestion method with the multiple enzyme solution.

Keywords: dermal fibroblast, isolation, cultivation, enzyme digestion

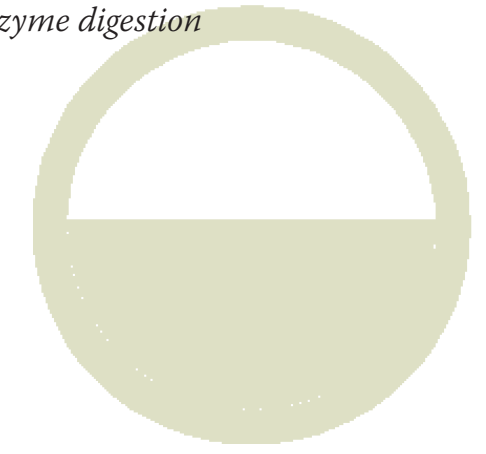

DE GRUYTER
OPEN

\section{SAŽETAK}

Kultivisani fibroblasti se često upotrebaljavaju u brojnim „in vitro" studijama. Iako oni relativno lako proliferišu u uslovima ćelijskih kultura, standarne metode primarne izolacija fibroblasta nisu dovoljno efikasne. U ovom radu mi prikazujemo modifikovanu metodu enzimske digestije tkiva $i$ upoređujemo njene rezultate sa standardnim metodama.

U eksperimenu su korišćena tri uzorka dobijena nakon cirkumcizije kod mladih, sredovečnih $i$ starih pacijeneta. Uporedivana je efikasnost primarne izolacije fibroblasta korišćenjem eksplant metode, standardne enzimske metode uz korišćenje kolagenaze i naše modifikovane metode enzimske digestije tkiva. Upoređivano je vreme neophodno za dostizanje 95\% konfluencije fibroblasta u $30 \mathrm{~mm}$ Petri šoljama.

Eksplant metoda je najsporija kada je u pitanju dostizanje konfluencije i to posebno kod starih donora (do 23 dana). Standardna metoda enzimske digestije dovodi do nepotpune disocijacije tkiva humane kože, ali je dostizanje konfluencije fibroblasta bilo znatno brže nego kod eksplanta (kod mladih donora polovinom 7. dana). Naša, modifikovana enzimska metoda sa mešavinom enzima je najbrže dovela do konfluencije ćelija (kod mladih donora 5. dana).

Kada dizajn neke studije zahteva efikasnu izolaciju dermalnih fibroblasta $i$ visok procenat vijabilnosti ćelija, najbolja metoda je digestija tkiva sa mešavinom enzima.

Ključne reči: dermalni firboblasti, izolacija, kultivacija, enzimska digestija
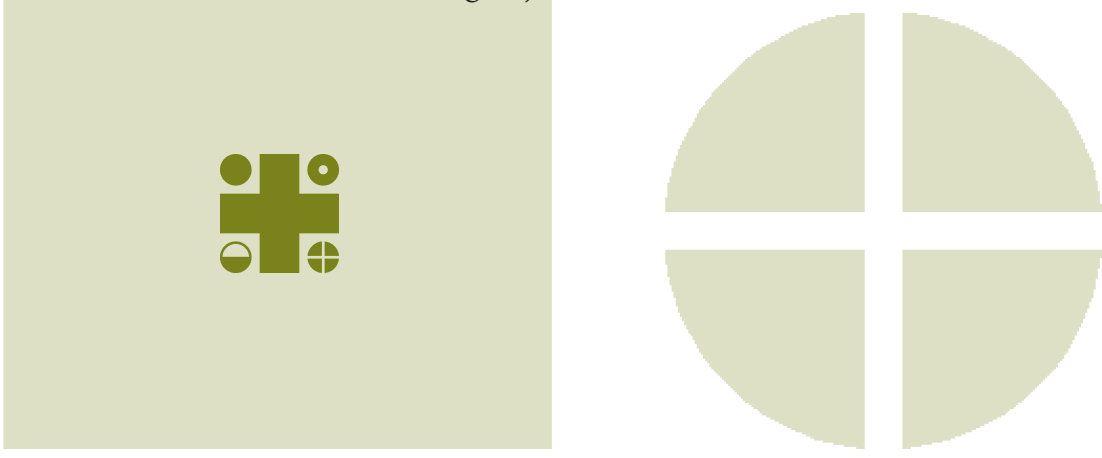

UDK: 575.853.085 / Ser J Exp Clin Res 2015; 16 (1): 65-69 DOI: 10.1515/SJECR-2015-0010

Corresponding author: Prof. Dr. Zoran Milosavljevic, Faculty of Medical Sciences Kragujevac, Institute for Histology and Embryology, 


\section{INTRODUCTION}

Fibroblasts are the main cell population in the dermal part of the skin. They play a crucial role in the maintenance of the normal histological organisation of the dermis and the repairing of wounded connective tissue. In the dermis of the skin, there are two different layers of connective tissue (1), including the papillary layer, which is mainly composed of loose connective tissue with a large number of biologically active fibroblasts, and the reticular layer, which is largely comprised of dense irregular, connective tissue that contains less fibroblasts with weaker mitotic activity $(2,3)$. In the cell culture system, fibroblasts readily proliferate in the presence of bovine sera and even a small amount of nutrients in the medium and frequently overgrow other cells in cultivation dishes; thus, they are commonly referred to as "weeds" of cell cultures (4). Considering that cultivated fibroblasts have been widely used in a great number of in vitro studies, ranging from examinations of metabolic pathways, cell-to-cell interactions, and drug effects to tissue engineering and genetic investigations, determining a reliable and quick method for the isolation and establishment of healthy primary fibroblast cultures is important (5-10). Although most studies have been performed on fibroblast cell lines purchased from cell factories, experiments with laboratory animals frequently require primary isolation for the confirmation of results obtained from cell cultures. There are few studies in the literature providing data on the improvement of isolation protocols, especially with regard to the shortening of the time necessary to establish healthy primary cultures and improvements in total cell yields $(11,12)$. Authors have agreed that the main success-limiting factors are the tissue type and the age of the donor. Younger and especially embryonic connective tissues are potent sources of fast-growing fibroblasts. In contrast, dense tissues from older donors may present significant problems for successful fibroblast culture establishment (13). In research laboratories, two major methods of fibroblast isolation are typically used, tissue explant and enzyme digestion with different types of matrix metalloproteinases, particularly collagenase (10-16). The main disadvantage of the explant method is the fact that it generates cells quite slowly (15). On the other hand, enzyme digestion can generate a great number of fibroblasts quickly, but problems that are mainly due to incomplete tissue digestion may occur when a small amount of tissue is to be processed $(17,18)$. Here, we present an improved protocol for fibroblast isolation and compare its efficiency with those of the standard explant and enzymatic methods.

\section{MATERIALS AND METHODS}

Foreskin samples from the three donors were used. All experiments were performed according to the $\mathrm{EU}(86 / 609$ / EEC) and local ethical guidelines with consent from the donors. The ages of the donors were 18, 34 and 68 years for samples one, two and three, respectively. All donors underwent a circumcision procedure, and their skin was found to be absent of pathological changes. The skin samples were kept in sterile saline solution with antibiotics, and all samples were processed within three hours. After the removal of excess tissue, the samples were transferred to a sterile dispase II $(20 \mathrm{mg} / \mathrm{ml}$, Sigma-Aldrich, USA) solution overnight at $8^{\circ} \mathrm{C}$. Then, the epidermis was peeled off with tweezers. The remaining tissue was finely minced with scissors to obtain small dermal pieces of approximately $1 \mathrm{~mm}$ in diameter. The skin tissue was then measured, and 18 grams of tissue from each sample were divided into three equal parts to be used for each isolation method so that the same amount of skin tissue would be evaluated in each case. Three different methods for the isolation of dermal fibroblasts were used as follows: the explant technique, the standard enzymatic dissociation procedure with collagenase II $(10 \mathrm{mg} / \mathrm{ml}$ (Gibco, USA), overnight at $37^{\circ} \mathrm{C}$ ) and our isolation procedure with a "mixed" enzyme solution $(10 \mathrm{mg} / \mathrm{ml}$ collagenase II, $5 \mathrm{mg} /$ $\mathrm{ml}$ dispase II, $1 \mathrm{mg} / \mathrm{ml}$ DNase (Invitrogen, USA), and 10 $\mathrm{mM}$ calcium-chloride (Sigma-Aldrich, USA), overnight at $40^{\circ} \mathrm{C}$ ). For the explant method, pieces of tissue from each donor were transferred into three $30-\mathrm{mm}$ Petri dishes, and cell culture medium was added. Tissue lysates obtained by enzyme digestion were inspected for the degree of digestion and cell viability using a fluorescence microscope with an acridine orange/ethidium bromide fluorescent dye. The cells were then isolated by washing in the buffer solution and centrifugation. Isolated fibroblasts from each donor were seeded in six Petri dishes. All cells were cultivated in low-glucose DMEM medium (Invitrogen, USA). The medium was changed every other day, and the time needed for the cells to reach over 95\% confluence in the $30-\mathrm{mm}$ Petri dishes was then measured. Near the end of the experiment, transparent millimeter paper was attached under the bottom of the Petri dish and used to assess the degree of confluence. All values were expressed as the mean \pm standard deviation (SD). Commercial SPSS version 20.0 for Windows (SPSS version 20.0; SPSS Inc., Chicago, IL, USA) was used for statistical analysis. The data distributions were evaluated for normality using the Shapiro-Wilk test. Statistical evaluation was performed by Student's t-test for paired observations or one-way ANOVA, depending on the data distribution. P values of less than 0.05 were considered significant.

\section{RESULTS}

The results of the three different fibroblast isolation methods are described as follows. With the explant method, the fibroblasts started to show outgrowth after 4-9 days. The earliest outgrowth was observed with the tissue obtained from sample 1 (mean value of $102 \pm 19$ hours), while sample 2 showed the same results, but with a delay 


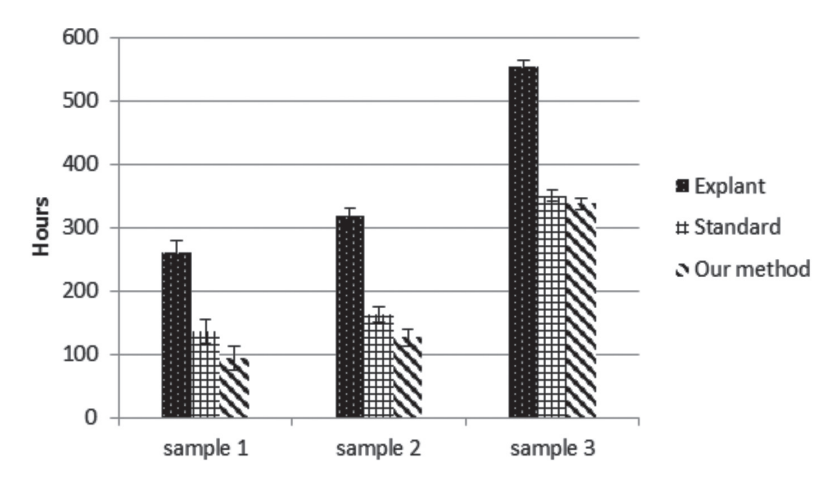

Figure 1: Time needed for 95\% fibroblast confluence in relation to donor age and the type of cell isolation method used.

of almost two days (mean value of $138 \pm 14$ hours). Cell outgrowth of sample 3 (the oldest donor) failed to occur in one Petri dish (after 3 weeks), and the others showed proliferation within $204 \pm 12$ hours. The desired $95 \%$ cell confluence was reached on the $11^{\text {th }}$ day ( $261 \pm 19$ hours) for sample 1 and the $14^{\text {th }}$ day for sample 2 ( $318 \pm 26$ hours). For sample 3 , cells in two Petri dishes did not reach confluence even after 4 weeks, but for the other 3 specimens, confluence was reached on the $23^{\text {rd }}$ day ( $554 \pm 46$ hours) (Fig. 1).

With the standard enzyme digestion method, the fibroblasts from sample 1 reached confluence in 6 days $(137 \pm 13$ hours), and confluence was reached in 7 days for sample 2

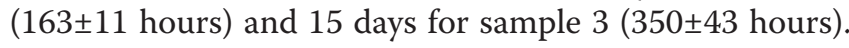
Tissue digestion was not complete because a significant number of fibroblasts were still trapped inside of the collagen fibre mesh after the treatment (Fig. 2).

Our improved enzyme digestion method with a "mixed" enzyme solution was found to be the most effective. The fibroblasts from the youngest donor reached 95\% confluence in 4 days ( $94 \pm 9$ hours), while the cells from sample 2 achieved this goal after 5 days $(127 \pm 12$ hours). Interestingly, although the digestion of the dermal tissue from the oldest donor was better with our method than with standard enzyme digestion method, the fibroblasts isolated by our method reached the $95 \%$ confluence at roughly at the same time as those isolated by the standard method (338 \pm 36 hours) (Fig. 1).

Statistical analysis showed that the fibroblasts isolated by both enzyme digestion methods reached $95 \%$ confluence significantly faster $(\mathrm{p}<0.05)$ than those isolated with the explant method. A comparison of the two enzyme digestion methods showed that for sample 1 (the young donor), our method allowed for the desired number of cells to be obtained significantly faster $(\mathrm{p}<0.05)$, but this did not occur for the middle-aged and older donors ( $\mathrm{p}>0.05)$.

\section{DISCUSSION}

Fibroblasts are the most abundant cells in the human body. Their main role is to produce fibres and components of the extracellular matrix of connective tissues
$(1,2)$. Because they readily proliferate under cell culture conditions, they have been widely used in various in vitro studies (5-10). Their primary isolation and cultivation methods have been known for decades (16), but reports of improvements in these techniques are rare and have not been very effective (19). As expected, our study showed that the explant method for the isolation and cultivation of dermal fibroblasts was by far the slowest way to obtain the desired number of these cells compared to the enzyme digestion methods, even when considering the one-day advantage of the explant method (the other methods needed one additional day for digestion). This fact has been well documented in previous publications (15). Although there are some differences between our findings and results from other studies concerning the time that fibroblasts need to start outgrowth from the tissue and proliferate to the desired number, these discrepancies are due to the uses of unequal starting amounts of skin tissue. Nevertheless, we can agree that the explant method should not be used when cultured dermal fibroblasts are needed quickly. This is especially true when the starting tissue originates from older donors because in this case, the explant method is not reliable due to the frequent failure of fibroblast outgrowth that has been observed. In our study, failure occurred in $50 \%$ of the cases, if we include the specimens that did not reach $95 \%$ confluence. A much faster way to obtain a primary dermal fibroblast culture is the enzyme digestion technique $(11,12,17)$. For this technique, the collagenase II enzyme is most commonly used to break up collagen fibres and release fibroblasts from connective tissue. Our results showed that this method is reliable and produces enough cells for a relatively fast cultivation onset. However, in this study, we tried to fully utilise the histological architecture of the skin and enzymatic characteristics to improve the isolation procedure. Considering the two distinct parts of the dermis and especially the structural characteristics of the papillary layer, we assumed that

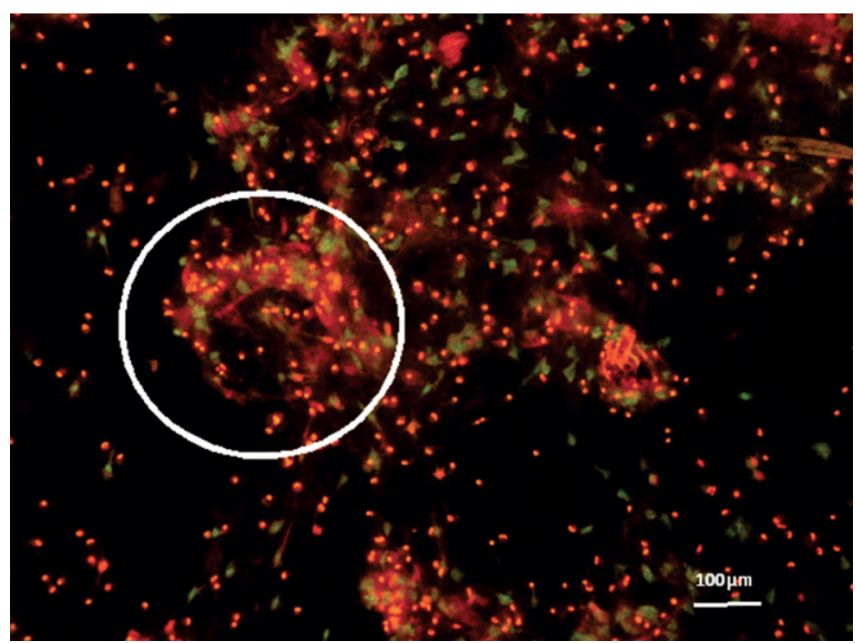

Figure 2: Incomplete digestion. Cells trapped In collagen fiber mash cells (encircled) 
proteases, such as dispase II, would enhance cell release by breaking down the attachment of the fibroblast to the collagen fibres because this enzyme hydrolyses peptides bound to non-polar amino acids, which are often found in collagen $(20,21)$. The results proved that this assumption was correct. The digestion of the young dermal tissue was better with the "mixed" enzyme solution, and the tissue specimens treated with our solution gave rise to more fibroblasts that reached $95 \%$ confluence more rapidly than the ones obtained with the standard enzyme digestion method. Furthermore, our method included an elevated calcium concentration and a higher temperature than usual because calcium ions are important for the ability of collagenase to bind to collagen fibres and start digestion, and the activity of this enzyme is higher at slightly elevated temperatures $(22,23)$. The only major exception occurred when tissue samples from older donors were investigated. In these cases, the "mixed" enzyme solution failed to produce more cells than the standard one, and the fibroblasts reached confluence at virtually the same time. This is surely because of the atrophic changes in the skin of elderly individuals, including reduced cellularity and a significant increase in collagen content (13). Older dermal tissue is denser and less responsive to enzymatic treatment. In addition, fibroblasts lose mitotic potential with age; thus, the overall effect of the digestion solution was diminished. We were somewhat puzzled by the results concerning the middle-aged donors. We expected results similar to those obtained with the younger tissue e.g., the significant improvement of cell isolation, but tissue digestion with the combined enzyme solution was not as complete compared with the young donor. There was some difference in favour of the "mixed" enzyme solution compared to the standard one, but it was not significant. This is probably also due to the structural changes of the skin; therefore, we are in agreement with some authors who have stated that the aging process of the human skin is already apparent during the fourth decade of life $(24,25)$.

\section{REFERENCES}

1. M. Ross , W. Pawlina. Histology of the skin. In Histology: A Text and Atlas 6th edition, Lippincott Williams \& Wilkins 2010; 493-501.

2. M. Ross , W. Pawlina. Histology of the skin. In Histology: A Text and Atlas 6th edition, Lippincott Williams \& Wilkins 2010; 183-185.

3. Boo S, Dagnino L. Integrins as Modulators of Transforming Growth Factor Beta Signaling in Dermal Fibroblasts During Skin Regeneration After Injury. Adv. Wound Care 2013; 2(5): 238-246.

4. Miron-Mendoza M, Lin X, Ma L, Ririe P, Petroll WM. Individual versus collective fibroblast spreading and migration: regulation by matrix composition in 3D culture. Exp Eye Res. 2012; 99: 36-44.
5. Bojesen KB, Clausen O, Rohde K, Christensen C, Zhang L, Li S, Kohler L, Nielbo S, Nielsen J, Gjorlund MD, Poulsen FM, Bock E, Berezin V. Nectin-1 binds and signals through the fibroblast growth factor receptor. J Biol Chem. 2012; 26; 287(44): 37420-33.

6. Chung B, Hinek A, Keating S, Weksberg R, Shah V, Blaser S, Hawkins C, Chitayat D Overgrowth with increased proliferation of fibroblast and matrix metalloproteinase activity related to reduced TIMP1: a newly recognized syndrome? Am J Med Genet A. 2012; 158A(10): 2373-81.

7. Miron-Mendoza M, Lin X, Ma L, Ririe P, Petroll WM. Individual versus collective fibroblast spreading and migration: regulation by matrix composition in 3D culture. Exp Eye Res. 2012; 99: 36-44.

8. Erisken C, Zhang X, Moffat KL, Levine WN, Lu HH. Scaffold fiber diameter regulates human tendon fibroblast growth and differentiation. Tissue Eng Part A. 2013; 19(3-4): 519-28.

9. Itoh N, Ornitz DM. Fibroblast growth factors: from molecular evolution to roles in development, metabolism and disease. J Biochem. 2011; 149(2): 121-30.

10. H. Jiang and F. Grinnell. Cell-Matrix Entanglement and Mechanical Anchorage of Fibroblasts in Threedimensional Collagen Matrices. Molecular Biology of the Cell. 2005; 16: 5070-5076.

11. Huang $\mathrm{HI}, \mathrm{Wu} \mathrm{CZ}$. Isolation and differentiation potential of fibroblast-like stromal cells derived from human skin. Methods Mol Biol. 2012; 879:465-70.

12. Park JC, Kim YB, Kim HJ, Jang HS, Kim HS, Kim BO, Han KY. Isolation and characterization of cultured human periodental ligament fibroblast-specific cDNAs. Biochem Biophys Res Commun. 2001; 20; 282(5): 1145-53.

13. A. Tiganescu, W Parish, E. Walker, M. Cooper, G. Lavery, P. Stewart. Reversal of age-induced dermal atrophy in $11 \beta$-hydroxysteroid dehydrogenase type 1-null mice. Endocrine Abstracts 2012; 28, P302.

14. McElreavey KD, Irvine AI, Ennis KT, McLean WH. Isolation, culture and characterisation of fibroblastlike cells derived from the Wharton's jelly portion of human umbilical cord. Biochem Soc Trans. 1991; 19(1): 29 S.

15. Goldschmidt E, Hem S, Ajler P, Ielpi M, Loresi M, Giunta D, Carrizo A, Yampolsky C, Argibay P. A new model for dura mater healing: human dural fibroblast culture. Neurol Res. 2013; 35(3): 300-7.

16. Hentzer B, Kobayasi T. Enzymatic liberation of viable cells of human skin. Acta Derm Venereol. 1978;58(3):197-202.

17. De Falco E1, Scafetta G, Napoletano C, Puca R, Vingolo EM, Ragona G, Iorio O, Frati G. Cell Tissue Bank. 2013; 14(2): 277-87. Epub 2012; 21. A standardized laboratory and surgical method for in vitro culture isolation and expansion of primary human Tenon's fibroblasts.

18. McFarland KL, Glaser K, Hahn JM, Boyce ST, Supp DM. Culture medium and cell density impact gene ex- 
pression in normal skin and abnormal scar-derived fibroblasts. J Burn Care Res. 2011; 32(4): 498-508.

19. Wang H, Van Blitterswijk CA, Bertrand-De Haas M, Schuurman AH, Lamme EN. Improved enzymatic isolation of fibroblasts for the creation of autologous skin substitutes. in Vitro Cell Dev Biol Anim. 2004; 40(8-9): 268-77.

20. http://www.lifetechnologies.com/order/catalog/ product/17105041.

21. Fields, Gregg B. Interstitial collagen catabolism. Journal of Biological Chemistry 288.13 2013; 8785-8793.

22. Tezvergil-Mutluay A, Agee KA, Hoshika T, Carrilho M, Breschi L, Tjaderhane L, Nishitani Y, Carvalho RM, Looney S, Tay FR, Pashley DH. The requirement of zinc and calcium ions for functional MMP activity in demineralized dentin matrices. Dent Mater. 2010; 26(11): 1059-6.

23. Shrinivas, D. and G. R. Naik. Characterization of alkaline thermostable keratinolytic protease from thermoalkalophilic Bacillus halodurans JB 99 exhibiting dehairing activity. International Biodeterioration \& Biodegradation 65.1 (2011): 29-35.

24. Zouboulis, Christos C. and Evgenia Makrantonaki. Clinical aspects and molecular diagnostics of skin aging. Clinics in dermatology 29.1, 2011; 3-14.

25. Longo, Caterina, et al. Skin aging: in vivo microscopic assessment of epidermal and dermal changes by means of confocal microscopy. Journal of the American Academy of Dermatology 68.3, 2013; e73-e82. 